\title{
Considerations of Pool Dimensions in the Forced Swim Test in Predicting the Potential Antidepressant Activity of Drugs
}

\author{
Gilberto Uriel Rosas-Sánchez ${ }^{1,2}$, León Jesús German-Ponciano ${ }^{2}$ and \\ Juan Francisco Rodríguez-Landa ${ }^{2 *}$ \\ ${ }^{1}$ Programa de Doctorado en Neuroetología, Instituto de Neuroetología, Universidad Veracruzana, Xalapa, Mexico, \\ ${ }^{2}$ Laboratorio de Neurofarmacología, Instituto de Neuroetología, Universidad Veracruzana, Xalapa, Mexico
}

Keywords: antidepressant activity, behavior, forced swim test pool, immobility behavior, psychopharmacology

\section{INTRODUCTION}

The forced swim test (FST) was proposed by Porsolt et al. (1977a,b) as a relatively rapid test to identify new compounds with potential antidepressant activity in rats and mice. In this test, the total time of immobility (TTI) was proposed as a variable that reflects despair-like behavior, which could be reduced by clinically effective antidepressants (Porsolt et al., 1977a, 1978). Since then, diverse interpretations of immobility in the FST have arisen, including behavioral despair, learned helplessness, and depression-like behavior, even considering the FST as an animal model of depression (Porsolt, 2000; Cryan and Mombereau, 2004). Immobility was interpreted as a passive coping strategy, anxiety, and psychomotor retardation or as a behavior that is related to autism spectrum disorder (Anyan and Amir, 2018; Unal and Canbeyli, 2019). A reduction of immobility in the FST by drugs was interpreted as an antidepressant-like effect because clinically effective antidepressant drugs significantly reduce this behavior (Dalvi and Lucki, 1999; Porsolt, 2000). Important discussions of the meaning and interpretation of immobility in the FST in mice and rats have occurred (Molendijk and de Kloet, 2019, 2021), questioning whether the FST should or should not be considered an experimental model of depression that reproduces in rodents the large spectrum of complex signs and symptoms that characterize clinical depression (Molendijk and de Kloet, 2021). Additionally, discussions about ethical issues related with the FST have arisen questioning its use in the preclinical research of antidepressant drugs (Reardon, 2019; Trunnell and Carvalho, 2021). The relevance of this kind of discussion highlights the following: "...we must critically assess how we are interpreting complex animal behavior to ensure we are not overly interpreting behaviors or potential missing out on alternative and fruitful direction" (Gorman-Sandler and Hollis, 2021).

The present opinion article discusses how pool dimensions, among other factors, can influence the detection of immobility in the FST and how these dimensions may permit or prevent the detection of an anti-immobility effect of relatively low doses of antidepressant drugs.

Accepted: 02 December 2021

Published: 07 January 2022

Citation:

Rosas-Sánchez GU, German-Ponciano LJ and

Rodríguez-Landa JF (2022) Considerations of Pool Dimensions in the Forced Swim Test in Predicting the

Potential Antidepressant Activity of

\section{THE FORCED SWIM TEST}

The FST is one of the most used behavioral tests in preclinical research to evaluate substances with potential antidepressant activity in mice and rats (Yankelevitch-Yahav et al., 2015; Anyan and Amir, 2018; Kazavchinsky et al., 2019) and pharmacological interactions between endogenous and exogenous molecules, such as between hormones and antidepressant drugs, between hormones and natural products, and between synthetic drugs and natural products (Estrada-Camarena et al., 2004, 2006; Shah et al., 2006; Poleszak et al., 2016; Cueto-Escobedo et al., 2020). Generally, 
antidepressant drugs reduce TTI in the FST in the absence of significant motor effects, which has been considered antidepressant activity (Koek et al., 2018; Unal and Canbeyli, 2019). Interestingly, a reduction of immobility that is produced by antidepressant drugs is associated with specific changes in serotonergic, noradrenergic, dopaminergic, and $\gamma$-aminobutyric acid-ergic neurotransmission (Shishkina et al., 2012; Ulloa et al., 2014), changes in neuronal activity (Contreras et al., 2000, 2001; Filho et al., 2015), and the expression of neurotrophic factors (Branchi et al., 2013; Filho et al., 2015; Vilela-Costa et al., 2021) in several brain structures that are involved in the neurobiology of depressive disorders.

Porsolt et al. (1977a) described in their original study that male Sprague-Dawley rats were forced to swim for $15 \mathrm{~min}$ in a Plexiglas cylinder ( $40 \mathrm{~cm}$ height, $18 \mathrm{~cm}$ diameter) that was filled with $25^{\circ} \mathrm{C}$ water. These rats exhibited long periods of immobility, mild hypothermia, and motor hypoactivity, which the authors considered "a state of lowered mood in the rat." Interestingly, $24 \mathrm{~h}$ later, when the rats were forced to swim again for $5 \mathrm{~min}$, they remained immobile for $75 \%$ of the test duration. This immobility was then reduced by antidepressant drugs (e.g., tricyclic antidepressants, monoamine oxidase inhibitors, and atypical antidepressants) and electroconvulsive shock, without significantly affecting motor activity. The authors considered that this reduction of immobility could be used as an effective tool that is "capable of discovering new types of antidepressant agents hitherto undetectable using classical screening test" (Porsolt et al., 1977a). The FST has also been adapted to evaluate the effect of antidepressant drugs in mice (Porsolt et al., 1977b; YankelevitchYahav et al., 2015). Mice are forced to swim in a Plexiglas cylinder ( $24 \mathrm{~cm}$ height, $13 \mathrm{~cm}$ diameter) containing water $\left(22 \pm 2^{\circ} \mathrm{C}\right)$ to a depth of $10 \mathrm{~cm}$. Different to rats, in mice there is only one session $6 \mathrm{~min}$ long divided into pretest (the first $2 \mathrm{~min}$ ) and test (the last $4 \mathrm{~min}$ ). Under these experimental conditions antidepressant drugs significantly also reduce TTI.

\section{CHANGES IN DIMENSIONS OF POOLS USED IN THE FST}

The pool characteristics in Porsolt's original model (i.e., water depth, cylinder diameter, and water temperature) have been modified to evaluate the effect of antidepressant drugs on immobility in mice and rats (Borsini et al., 1986; Yates et al., 1991; Sunal et al., 1994). Although the influence of pool dimensions on immobility has been scarcely studied, evidence suggests that it may impact this behavior. Sunal et al. (1994) modified the diameter of the cylinder and water depth so that animals could touch the walls and bottom of the pool with their paws and tail. They used vertical cylinders with different diameters $(10,20,30$, and $50 \mathrm{~cm}$ ) that were filled with water to a depth of $20 \mathrm{~cm}$. The TTI was evaluated in male and female albino mice (Charles River) from 3 to $6 \mathrm{~min}$ in a single 15 -min swim session. Under these conditions, higher immobility was detected when animals were tested in cylinders with the smaller diameters $(10$ and $20 \mathrm{~cm}$ ), with an apparent influence of the mice being allowed to touch the walls with their paws. Conversely, lower immobility was detected in animals that were evaluated in cylinders with larger diameters ( 30 and $50 \mathrm{~cm}$ ) because they could not touch the walls and thus were forced to swim (Sunal et al., 1994). Under these conditions, a single intraperitoneal (i.p.) injection of 10 and 20 $\mathrm{mg} / \mathrm{kg}$ clomipramine and tranylcypromine, and 7.5 and $15 \mathrm{mg} / \mathrm{kg}$ maprotiline, significantly reduced TTI, but the pool dimension variable clearly affected TTI.

Other authors also modified the water depth from 15-18 to $30 \mathrm{~cm}$ (Detke and Lucki, 1996). Under this condition, male Sprague-Dawley rats exhibited high immobility and two additional behaviors, swimming and climbing. Swimming was associated with activation of the serotonergic system because selective serotonin reuptake inhibitors $(20 \mathrm{mg} / \mathrm{kg}$ fluoxetine) increased swimming behavior, and climbing was related to activation of the noradrenergic systems because selective norepinephrine reuptake inhibitor (10 $\mathrm{mg} / \mathrm{kg}$ desipramine) selectively increased this behavior after subcutaneous injection 23, 5, and $1 \mathrm{~h}$ prior to the test. Both antidepressant drugs significantly reduced TTI. Thus, modifications of pool characteristics permitted the identification of specific behaviors that are associated with the activation of particular neurotransmitter systems. Importantly, immobility behavior can be modified not only by antidepressant drugs but also by the dimensions of the pool that is used for the FST (Sunal et al., 1994). Methodological differences among laboratories can influence the measurement of immobility and subsequently identification of the potential antidepressant activity of drugs.

Contreras et al. (1995) introduced a rectangular pool $(50 \times$ $30 \mathrm{~cm}$ base, $60 \mathrm{~cm}$ height) to evaluate the effect of antidepressant drugs in Wistar rats. They evaluated TTI as an indicator of antidepressant-like activity and, additionally, measured the latency to the first period of immobility (LI). This latter variable was considered an indicator of the first effort of the rat to search for an exit and escape the stressful situation that was represented by the FST (Contreras et al., 1998). In this rectangular pool, Wistar rats injected with clomipramine (2.5 mg/kg/28-days, i.p.), desipramine (2.1 mg/kg/21-days i.p.), fluoxetine $(0.5,1$, and $2 \mathrm{mg} / \mathrm{kg} / 21$-days i.p.), and Swiss albino mice treated with paroxetine $(0.5,1$, and $2 \mathrm{mg} / \mathrm{kg} / 21$-days, p.o.) (Contreras et al., 1995, 1998, 2001; Amaghnouje et al., 2020a), as well as Wistar rats injected with progesterone (0.8, 1.6 , and $3 \mathrm{mg} / \mathrm{kg}, 24$ and $2 \mathrm{~h}$ before testing), allopregnanolone (1, 2, and $3 \mathrm{mg} / \mathrm{kg}, 1 \mathrm{~h}$ before testing) (Martinez-Mota et al., 1999; Molina et al., 1999a; Rodriguez-Landa et al., 2007; CuetoEscobedo et al., 2020), some extracts (Wistar rats: 6.43 and 7.14 $\mathrm{mg} / \mathrm{kg} / 21$-days Hypericum perforatum and $50 \mathrm{mg} / \mathrm{kg} / 1$-28-days Montanoa frutescens and Montanoa grandiflora; Swiss Albino mice: 250 and $500 \mathrm{mg} / \mathrm{kg} / 1-21$-days Origanum majorana extract, p.o.), and some metabolites from plants (Wistar rats: single doses of $1 \mathrm{mg} / \mathrm{kg}$ chrysin, i.p., Swiss albino mice: 50 and 100 $\mathrm{mg} / \mathrm{kg} / 1-21$-days polyphenols, p.o.) (Lozano-Hernández et al., 2010; Rodríguez-Landa et al., 2018, 2020; Amaghnouje et al., 2020a,b) significantly reduced TTI and, some of them, increased LI. Therefore, the measurement of LI, in addition to TTI, may improve the detection of antidepressant-like activity in the FST (Castagné et al., 2009). 
TABLE 1 | Representative effects of fluoxetine and other antidepressant drugs on immobility behavior in the forced swim test using cylindrical and rectangular pools.

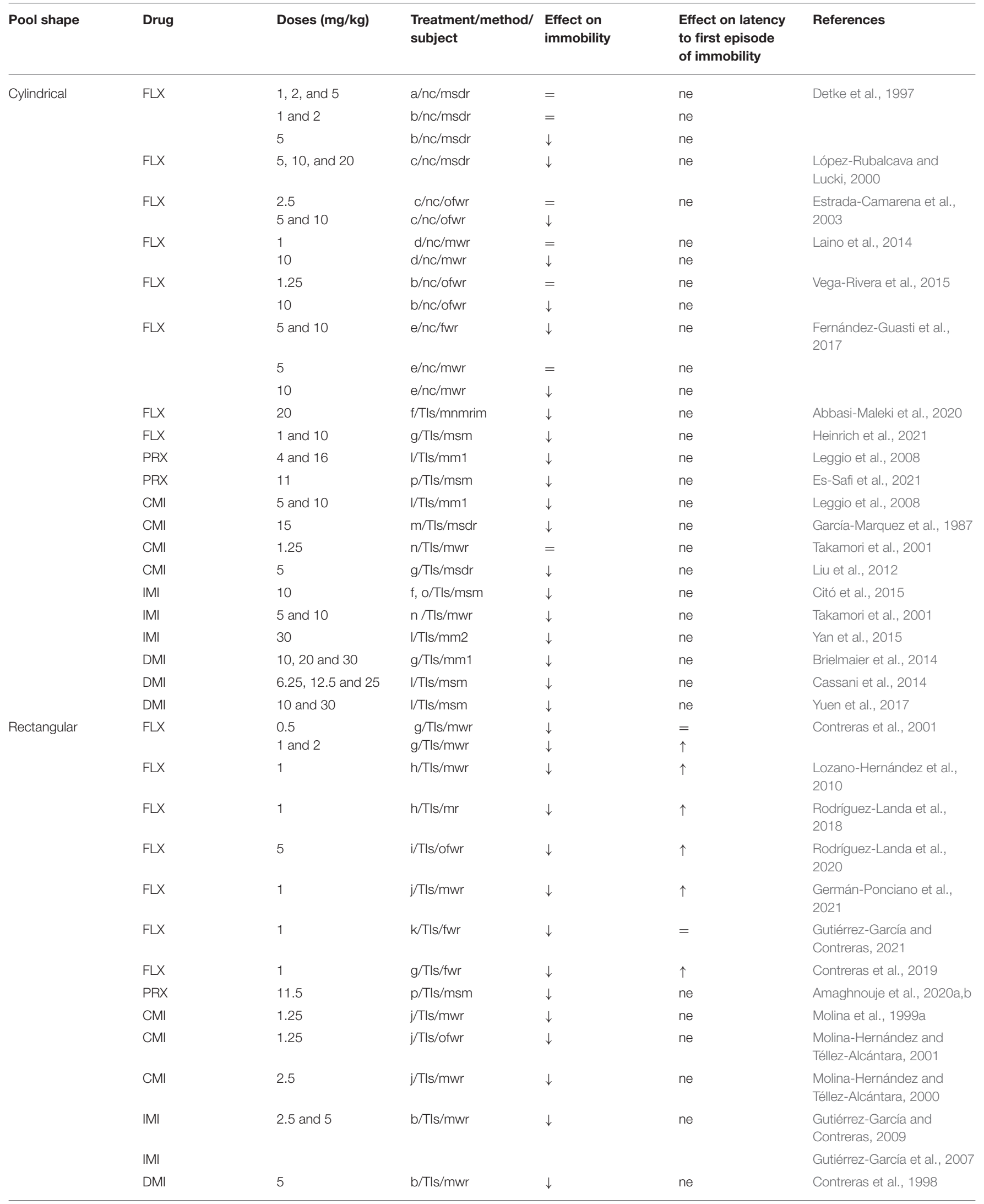


TABLE 1 | Continued

\begin{tabular}{|c|c|c|c|c|c|c|}
\hline Pool shape & Drug & Doses (mg/kg) & $\begin{array}{l}\text { Treatment/method/ } \\
\text { subject }\end{array}$ & $\begin{array}{l}\text { Effect on } \\
\text { immobility }\end{array}$ & $\begin{array}{l}\text { Effect on latency } \\
\text { to first episode } \\
\text { of immobility }\end{array}$ & References \\
\hline & $\mathrm{DMl}$ & 2.1 & $\mathrm{~g} / \mathrm{Tls} / \mathrm{mwr}$ & $=$ & $\uparrow$ & Molina et al., 1999a \\
\hline & DMI & & & & & Molina et al., 1999b \\
\hline & DMl & 2.14 & $\mathrm{j} / \mathrm{Tls} / \mathrm{mwr}$ & $\downarrow$ & ne & Gutiérrez-García et al., 2003 \\
\hline & & 32 & $\mathrm{f} / \mathrm{Tls} / \mathrm{mwr}$ & $\downarrow$ & ne & \\
\hline & & 10 & $\mathrm{n} / \mathrm{Tls} / \mathrm{mwr}$ & $\downarrow$ & ne & \\
\hline
\end{tabular}

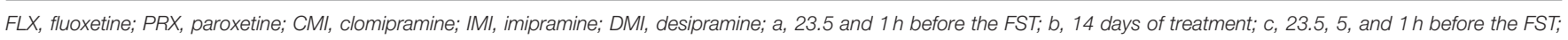

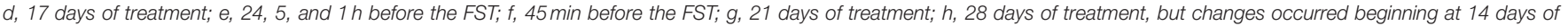

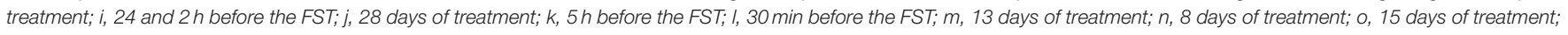

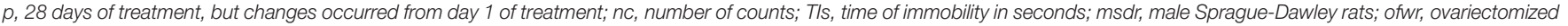

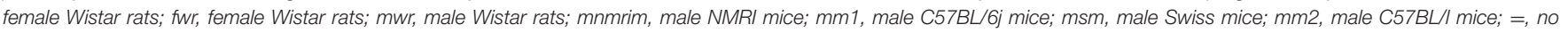
effect; ne, not evaluated; $\downarrow$, reduction of immobility; $\uparrow$, increase immobility.

Other modifications of the dimensions of the FST pool have been reported. Using a small rectangular pool $(30 \times 26 \mathrm{~cm}$ base, $50 \mathrm{~cm}$ height) allowed the detection of a reduction of TTI that was associated with proestrus-estrus in female Wistar rats (i.e., a stage of the estrous cycle when steroid hormones are higher; Hernández-López et al., 2017). This same effect was detected when a single i.p. injection of $1 \mathrm{mg} / \mathrm{kg}$ chrysin in male Wistar rats was evaluated in this pool (Germán-Ponciano et al., 2020). One limitation of this small rectangular pool, however, was that LI was not influenced by chrysin, whereas this same doses of chrysin significantly reduced TTI and increased LI in a larger rectangular pool (Cueto-Escobedo et al., 2020; Germán-Ponciano et al., 2021). These findings indicate that pool dimensions can influence behavioral variables that are used to detect the potential antidepressant activity of drugs.

\section{EFFECTS OF FLUOXETINE AND OTHER ANTIDEPRESSANT DRUGS ON IMMOBILITY IN THE FST USING CYLINDRICAL AND RECTANGULAR POOLS}

Generally, the doses of antidepressant drugs that are evaluated in a cylindrical pool are between 5 and $20 \mathrm{mg} / \mathrm{kg}$ (López-Rubalcava and Lucki, 2000; Fernández-Guasti et al., 2017; Abbasi-Maleki et al., 2020). Lower doses (e.g., $<2 \mathrm{mg} / \mathrm{kg}$ ) are generally ineffective in reducing immobility in mice and rats that are forced to swim (Detke et al., 1997; Estrada-Camarena et al., 2003: Vega-Rivera et al., 2016). Principally, fluoxetine is used as a pharmacological control for antidepressant activity to compare the effects of new substances with potential antidepressant activity in the FST. However, the effects of fluoxetine and other antidepressant drugs on immobility depend on dose, treatment duration, and pool characteristics (Table 1). The doses of fluoxetine that significantly reduce immobility in a cylindrical pool are $>5 \mathrm{mg} / \mathrm{kg}$ (López-Rubalcava and Lucki, 2000; EstradaCamarena et al., 2003; Laino et al., 2014). In this pool, the acute administration (23.5 and $1 \mathrm{~h}$ before the FST) of fluoxetine and desipramine (1,2, and $5 \mathrm{mg} / \mathrm{kg}$, s.c.) in male Sprague-Dawley rats was devoid of effects on immobility, whereas 14 days treatment with $5 \mathrm{mg} / \mathrm{kg}$ fluoxetine and desipramine (Detke et al., 1997), significantly reduced immobility in a cylindrical pool. Similar effects were detected in ovariectomized Wistar rats with same treatment (Estrada-Camarena et al., 2003).

Interestingly, chronic lower doses of fluoxetine $(0.5,1$, and 2 $\mathrm{mg} / \mathrm{kg} / 21$-days, p.o.) significantly reduced TTI when male Wistar rats were evaluated in a rectangular pool $(50 \times 30 \mathrm{~cm}$ base, $60 \mathrm{~cm}$ height), and 1 and $2 \mathrm{mg} / \mathrm{kg}$ fluoxetine also increased LI (Contreras et al., 2001, 2019). These doses were ineffective in the cylindrical pool. Long-term studies with a rectangular pool found a decrease in TTI and increase in LI that were produced by 1 $\mathrm{mg} / \mathrm{kg}$ fluoxetine from day 7 to day 14 of treatment, and this effect persisted until days 21 and 28 of treatment (Lozano-Hernández et al., 2010; Rodríguez-Landa et al., 2018; Germán-Ponciano et al., 2021). The acute administration of $5 \mathrm{mg} / \mathrm{kg}$ fluoxetine 24 and $2 \mathrm{~h}$ before the FST significantly reduced TTI in a rectangular pool and increased LI (Rodríguez-Landa et al., 2020), a variable that was not evaluated in the cylindrical pool (Estrada-Camarena et al., 2003). These findings indicate that the pool dimensions in the FST and treatment schedules have an important influence on immobility behavior and other variables, such as LI, that can improve the detection of antidepressant-like activity of drugs.

\section{CONCLUDING REMARKS}

Some modifications of pool dimensions in the FST (Sunal et al., 1994; Contreras et al., 2001), among other factors, have improved the identification of potential antidepressants drugs, but other modifications can also limit its detection (Germán-Ponciano et al., 2020). Few studies have evaluated the influence of pool dimensions on the effects of different doses of antidepressant drugs on immobility. An increase in the size or shape of the pool permits the measurement of other variables, such as the LI, in addition to the number of episodes of immobility and TTI that are generally evaluated in Porsolt's original model. Even a rectangular pool allows the identification of a decrease in TTI and an increase in LI with relatively low doses $(0.5-2 \mathrm{mg} / \mathrm{kg})$ of antidepressant drugs, such as fluoxetine, clomipramine and desipramine, which are otherwise ineffective in a cylindrical 
pool. This observation opens new directions to studying how changes in the dimensions of the pool that is used in the FST can contribute to more efficiently and effectively measuring immobility and other behaviors (e.g., swimming, climbing and diving, among others) as predictive of antidepressant activity in preclinical research. These observations should be considered when the FST is used to evaluate potential antidepressant activity of drugs.

\section{AUTHOR CONTRIBUTIONS}

JFR-L and GUR-S conceived the idea of the paper and developed its structure. GUR-S and LJG-P wrote the first draft of the

\section{REFERENCES}

Abbasi-Maleki, S., Kadkhoda, Z., and Taghizad-Farid, R. (2020). The antidepressant-like effects of Origanum majorana essential oil on mice through monoaminergic modulation using the forced swimming test. J. Trad. Complement. Med. 10, 327-335. doi: 10.1016/j.jtcme.2019.01.003

Amaghnouje, A., Mechchate, H., Es-safi, I., Alotaibi, A. A., Noman, O. M., Nasr, F. A., et al. (2020b). Anxiolytic, antidepressant-like proprieties and impact on the memory of the hydro-ethanolic extract of Origanum majorana L. on mice. Appl. Sci. 10:8420. doi: 10.3390/app10238420

Amaghnouje, A., Mechchate, H., Es-Safi, I., Boukhira, S., Aliqahtani, A. S., Noman, O. M., et al. (2020a). Subacute assessment of the toxicity and antidepressant-like effects of Origanum majorana L. polyphenols in Swiss albino mice. Molecules. 25:5653. doi: $10.3390 /$ molecules 25235653

Anyan, J., and Amir, S. (2018). Too depressed to swim or too afraid to stop? A reinterpretation of the forced swim test as a measure of anxiety-like behavior. Neuropsychopharmacology 43, 931-933. doi: 10.1038/npp.2017.260

Borsini, F., Volterra, G., and Meli, A. (1986). Does the behavioral "despair" test measure "despair"? Physiol. Behav. 38, 385-386. doi: 10.1016/0031-9384(86)90110-1

Branchi, I., Santarelli, S., Capoccia, S., Poggini, S., D’Andrea, I., Cirulli, F., et al. (2013). Antidepressant treatment outcome depends on the quality of the living environment: a pre-clinical investigation in mice. PLoS ONE. 8:E62226. doi: 10.1371/journal.pone. 0062226

Brielmaier, J., Senerth, J. M., Silverman, J. L., Matteson, P. G., Millonig, J. H., Di Cicco-Bloom, E., et al. (2014). Chronic desipramine treatment rescues depression-related, social and cognitive deficits in Engrailed-2 knockout mice. Genes Brain Behav. 13, 286-298. doi: 10.1111/gbb.12115 PMID: 24730055

Cassani, J., Dorantes-Barrón, A. M., Novales, L. M., Real, G. A., and Estrada-Reyes, R. (2014). Anti-depressant-like effect of kaempferitrin isolated from Justicia spicigera Schltdl (Acanthaceae) in two behavior models in mice: evidence for the involvement of the serotonergic system. Molecules 19, 21442-21461. doi: 10.3390/molecules 191221442

Castagné, V., Porsolt, R. D., and Moser, P. (2009). Use of latency to immobility improves detection of antidepressant-like activity in the behavioral despair test in the mouse. Eur. J. Pharmacol. 616, 128-133. doi: 10.1016/j.ejphar.2009. 06.018

Citó, M. C., Silva, M. I., Santos, L. K., Fernandes, M. L., Melo, F. H., Aguiar, J. A., et al. (2015). Antidepressant-like effect of Hoodia gordonii in a forced swimming test in mice: evidence for involvement of the monoaminergic system. Braz. J. Med. Biol. Res. 48, 57-64. doi: 10.1590/1414-431x201 44215

Contreras, C. M., Gutiérrez-García, A. G., and Moreno-Cortés, M. L. (2019). Responsivity of lateral septum-mPFC connections in alloxan-induced hyperglycemia. Behav. Brain Res. 368:111919. doi: 10.1016/j.bbr.2019.111919

Contreras, C. M., Lara-Morales, H., Molina-Hernández, M., Saavedra, M., and Arrellín-Rosas, G. (1995). An early lesion of the lateral septal nuclei produces changes in the forced swim test depending on manuscript. All authors selected and discussed the material to be included in the paper, reviewed, discussed, and approved the final version of the manuscript.

\section{FUNDING}

GUR-S received a fellowship from Consejo Nacional de Ciencia y Tecnología (CONACyT-Mexico, Reg. 592165) for doctoral studies in Neuroethology. This research is part of the SIREI project (no. DGI: 266502021159) registered by JFR-L, with partial financial support from Sistema Nacional de Investigadores (SNI, Exp. 32753). gender. Prog. Neuropsychopharmacol. Biol. Psychiatr. 19, 1277-1284. doi: 10.1016/0278-5846(95)00266-9

Contreras, C. M., Martínez-Mota, L., and Saavedra, M. (1998). Desipramine restricts estral cycle oscillations in swimming. Prog. Neuropsychopharmacol. Biol. Psychiatr. 22, 1121-1128. doi: 10.1016/s0278-5846(98)00066-9

Contreras, C. M., Molina, M., Saavedra, M., and Martinez-Mota, L. (2000). Lateral septal neuronal firing rate increases during proestrus-estrus in the rat. Physiol. Behav. 68, 279-284. doi: 10.1016/S0031-9384(99)00169-9

Contreras, C. M., Rodríguez-Landa, J. F., Gutiérrez-García, A. G., and BernalMorales, B. (2001). The lowest effective dose of fluoxetine in the forced swim test significantly affects the firing rate of lateral septal nucleus neurones in the rat. J. Psychopharmacol. 15, 231-236. doi: 10.1177/026988110101500401

Cryan, J. F., and Mombereau, C. (2004). In search of a depressed mouse: utility of models for studying depression-related behavior in genetically modified mice. Mol. Psychiatr. 9, 326-357. doi: 10.1038/sj.mp.4001457

Cueto-Escobedo, J., Andrade-Soto, J., Lima-Maximino, M., Maximino, C., Hernández-López, F., and Rodríguez-Landa, J. F. (2020). Involvement of GABAergic system in the antidepressant-like effects of chrysin (5, 7-dihydroxyflavone) in ovariectomized rats in the forced swim test: comparison with neurosteroids. Behav. Brain Res. 386:112590. doi: $10.1016 /$ j.bbr.2020.112590

Dalvi, A., and Lucki, I. (1999). Murine models of depression. Psychopharmacology. 147, 14-16. doi: 10.1007/s002130051131

Detke, M. J., Johnson, J., and Lucki, I. (1997). Acute and chronic antidepressant drug treatment in the rat forced swimming test model of depression. Exp. Clin. Psychopharmacol. 5, 107-112. doi: 10.1037//1064-1297.5.2.107

Detke, M. J., and Lucki, I. (1996). Detection of serotonergic and noradrenergic antidepressants in the rat forced swimming test: the effects of water depth. Behav. Brain Res. 73, 43-46. doi: 10.1016/0166-4328(96)00067-8

Es-Safi, I., Mechchate, H., Amaghnouje, A., Kamaly, O. M. A., Jawhari. F. Z., Imtara, H., et al. (2021). The potential of parsley polyphenols and their antioxidant capacity to help in the treatment of depression and anxiety: an in vivo subacute study. Molecules. 26, 2009. doi: 10.3390/molecules26072009

Estrada-Camarena, E., Fernández-Guasti, A., and López-Rubalcava, C. (2003). Antidepressant-like effect of different estrogenic compounds in the forced swimming test. Neuropsychopharmacology 28, 830-838. doi: 10.1038/sj.npp.1300097

Estrada-Camarena, E., Fernández-Guasti, A., and López-Rubalcava, C. (2004) Interaction between estrogens and antidepressants in the forced swimming test in rats. Psychopharmacology 173, 139-145. doi: 10.1007/s00213-003-1707-4

Estrada-Camarena, E., Lopez-Rubalcava, C., and Fernández-Guasti, A. (2006). Facilitating antidepressant-like actions of estrogens are mediated by $5-\mathrm{HT}_{1 \mathrm{~A}}$ and estrogen receptors in the rat forced swimming test. Psychoneuroendocrinology 31, 905-914. doi: 10.1016/j.psyneuen.2006.05.001

Fernández-Guasti, A., Olivares-Nazario, M., Reyes, R., and Martínez-Mota, L. (2017). Sex and age differences in the antidepressant-like effect of fluoxetine in the forced swim test. Pharmacol. Biochem. Behav. 152, 81-89. doi: 10.1016/j.pbb.2016.01.011 
Filho, C. B., Jesse, C. R., Donato, F., Giacomeli, R., Del Fabbro, L., da Silva Antunes, M., et al. (2015). Chronic unpredictable mild stress decreases BDNF and NGF levels and $\mathrm{Na}(+), \mathrm{K}(+)$-ATPase activity in the hippocampus and prefrontal cortex of mice: antidepressant effect of chrysin. Neuroscience 289, 367-380. doi: 10.1016/j.neuroscience.2014.12.048

García-Marquez, C., Giralt, M., and Armario, A. (1987). Long-lasting effects of chronic chlorimipramine treatment of rats on exploratory activity on a holeboard, and on immobility in the forced swimming test. Eur. J. Pharmacol. 142, 385-389. doi: 10.1016/0014-2999(87)90077-x

Germán-Ponciano, L. J., Puga-Olguín, A., Rovirosa-Hernández, M. J., Caba, M., Meza, E., and Rodríguez-Landa, J. F. (2020). Differential effects of acute and chronic treatment with the flavonoid chrysin on anxiety-like behavior and Fos immunoreactivity in the lateral septal nucleus in rats. Acta Pharm. 70, 387-397. doi: 10.2478/acph-2020-0022

Germán-Ponciano, L. J., Rosas-Sánchez, G. U., Ortiz-Guerra, S. I., Soria-Fregozo, C., and Rodríguez-Landa, J. F. (2021). Effects of chrysin on mRNA expression of $5-\mathrm{HT}_{1 \mathrm{~A}}$ and $5-\mathrm{HT}_{2 \mathrm{~A}}$ receptors in the raphe nuclei and hippocampus. Rev. Bras. Farmacogn. 31, 353-360. doi: 10.1007/s43450-021-00164-3

Gorman-Sandler, E., and Hollis, F. (2021). The forced swim test: Giving up on behavioral despair (Commentary on Molendijk and de Kloet, 2021). Eur. J. Neurosci. 6:15270. doi: 10.1111/ejn.15270

Gutiérrez-García, A. G., and Contreras, C. M. (2009). Stressors can affect immobility time and response to imipramine in the rat forced swim test. Pharmacol. Biochem. Behav. 91, 542-548. doi: 10.1016/j.pbb.2008.09.008

Gutiérrez-García, A. G., and Contreras, C. M. (2021). Putative anti-immobility action of acute insulin is attributable to an increase in locomotor activity in healthy Wistar rats. Neuropsychobiology 7, 1-10. doi: 10.1159/000515141

Gutiérrez-García, A. G., Contreras, C. M., Díaz-Meza, J. L., Bernal-Morales, B., Rodríguez-Landa, J. F., and Saavedra, M. (2003). Intraaccumbens dopaminergic lesion suppresses desipramine effects in the forced swim test but not in the neuronal activity of lateral septal nucleus. Prog. Neuropsychopharmacol. Biol. Psychiatry 27, 809-818. doi: 10.1016/S0278-5846(03)00113-1

Gutiérrez-García, A. G., Contreras, C. M., Mendoza-López, M. R., GarcíaBarradas, O., and Cruz-Sánchez, J. S. (2007). Urine from stressed rats increases immobility in receptor rats forced to swim: role of 2-heptanone. Physiol. Behav. 91, 166-172. doi: 10.1016/j.physbeh.2007.02.006

Heinrich, I. A., Freitas, A. E., Wolin, I. A., Nascimento, A. P. M., Walz, R., Rodrigues, A. L. S., et al. (2021). Neuronal activity regulated pentraxin (narp) and GluA4 subunit of AMPA receptor may be targets for fluoxetine modulation. Metabol. Brain Dis. 36, 711-722. doi: 10.1007/s11011-021-00675-x

Hernández-López, F., Rodríguez-Landa, J. F., Puga-Olguín, A., Germán-Ponciano, L. J., Rivadeneyra-Domínguez, E., and Bernal-Morales, B. (2017). Análisis de la actividad y coordinación motora en ratas con cirugía estereotáxica e implante de cánula en el hipocampo dorsal. Neurología 32, 579-586. doi: 10.1016/j.nrl.2016.03.004

Kazavchinsky, L., Dafna, A., and Einat, H. (2019). Individual variability in female and male mice in a test-retest protocol of the forced swim test. J. Pharmacol. Toxicol. Methods 95, 12-15. doi: 10.1016/j.vascn.2018.11.007

Koek, W., Sandoval, T. L., and Daws, L. C. (2018). Effects of the antidepressants desipramine and fluvoxamine on latency to immobility and duration of immobility in the forced swim test in adult male C57BL/6J mice. Behav. Pharmacol. 29:453. doi: 10.1097\%2FFBP.0000000000000371

Laino, C. H., Garcia, P., Podest,á, M. F., Höcht, C., Slobodianik, N., and Reinés, A. (2014). Fluoxetine potentiation of omega-3 fatty acid antidepressant effect: evaluating pharmacokinetic and brain fatty acid-related aspects in rodents. $J$. Pharm Sci. 103, 3316-3325. doi: 10.1002/jps.24123

Leggio, G. M., Micale, V., and Drago, F. (2008). Increased sensitivity to antidepressants of D3 dopamine receptor-deficient mice in the forced swim test (FST). Eur. Neuropsychopharmacol. 18, 271-277. doi: 10.1016/j.euroneuro.2007.07.003

Liu, Q., Zhu, H. Y., Li, B., Wang, Y. Q., Yu, J., and Wu, G. C. (2012). Chronic clomipramine treatment restores hippocampal expression of glial cell linederived neurotrophic factor in a rat model of depression. J. Affect. Disord. 141, 367-372. doi: 10.1016/j.jad.2012.03.018

López-Rubalcava, C., and Lucki, I. (2000). Strain differences in the behavioral effects of antidepressant drugs in the rat forced swimming test. Neuropsychopharmacology 22, 191-199. doi: 10.1016/S0893-133X(99)00100-1
Lozano-Hernández, R., Rodríguez-Landa, J. F., Hernández-Figueroa, J. D., Saavedra, M., Ramos-Morales, F. R., and Cruz-Sánchez, S. (2010). Antidepressant-like effects of two commercially available products of Hypericum perforatum in the forced swim test: A long-term study. J. Med. Plant Res. 4, 131-137. doi: 10.5897/JMPR.9000139

Martinez-Mota, L., Contreras, C. M., and Saavedra, M. (1999). Progesterone reduces immobility in rats forced to swim. Arch. Med. Res. 30, 286-289. doi: 10.1016/S0188-0128(99)00024-X

Molendijk, M. L., and de Kloet, E. R. (2019). Coping with the forced swim stressor: current state-of-the-art. Behav. Brain Res. 364, 1-10. doi: 10.1016/j.bbr.2019.02.005

Molendijk, M. L., and de Kloet, E. R. (2021). Forced swim stressor: Trends in usage and mechanistic consideration. Eur. J. Neurosci. 1-19. doi: 10.1111/ejn.15139

Molina, M., Contreras, C. M., and Téllez-Alcántara, P. (1999a). Mimosa pudica may possess antidepressant actions in the rat. Phytomedicine 6, 319-323. doi: 10.1016/S0944-7113(99)80052-X

Molina, M., Contreras, C. M., Téllez-Alcántara, P., and Rodríguez, F. (1999b). Sedative actions of Ternstroemia sylvatica in the male rat. Phytomedicine 6, 115-118. doi: 10.1016/S0944-7113(99)80045-2

Molina-Hernández, M., and Téllez-Alcántara, N. P. (2000). Long photoperiod regimen may produce antidepressant actions in the male rat. Prog. Neuropsychopharmacol. Biol. Psychiatry 24, 105-116. doi: 10.1016/s0278-5846(99)00084-6

Molina-Hernández, M., and Téllez-Alcántara, N. P. (2001). Antidepressantlike actions of pregnancy, and progesterone in Wistar rats forced to swim. Psychoneuroendocrinology 26, 479-491. doi: 10.1016/s0306-4530(01) 00007-5

Poleszak, E., Szopa, A., Wyska, E., Kukuła-Koch, W., Serefko, A., Wośko, S., et al. (2016). Caffeine augments the antidepressant-like activity of mianserin and agomelatine in forced swim and tail suspension tests in mice. Pharmacol. Rep. 68, 56-61. doi: 10.1016/j.pharep.2015.06.138

Porsolt, R. D. (2000). Animal models of depression: utility for transgenic research. Rev. Neurosci. 11, 53-58. doi: 10.1515/REVNEURO.2000.11.1.53

Porsolt, R. D., Anton, G., Blavet, N., and Jalfre, M. (1978). Behavioural despair in rats: a new model sensitive to antidepressant treatments. Eur. J. Pharmacol. 47, 379-391. doi: 10.1016/0014-2999(78)90118-8

Porsolt, R. D., Bertin, A., and Jalfre, M. (1977b). Behavioral despair in mice: a primary screening test for antidepressants. Arch. Int. Pharmacodyn. Ther. 229, 327-336.

Porsolt, R. D., Le Pichon, M., and Jalfre, M. L. (1977a). Depression: a new animal model sensitive to antidepressant treatments. Nature 266, 730-732. doi: $10.1038 / 266730 \mathrm{a} 0$

Reardon, S. (2019). Depression researchers rethink popular mouse swim tests. Nature 571, 456-457. doi: 10.1038/d41586-019-02133-2

Rodriguez-Landa, J. F., Contreras, C. M., Bernal-Morales, B., Gutierrez-Garcia, A. G., and Saavedra, M. (2007). Allopregnanolone reduces immobility in the forced swimming test and increases the firing rate of lateral septal neurons through actions on the GABAA receptor in the rat. J. Psychopharmacol. 21, 76-84. doi: 10.1177/0269881106064203

Rodríguez-Landa, J. F., Cueto-Escobedo, J., Flores-Aguilar, L. A., Rosas-Sánchez, G. U., Rovirosa-Hernández, M. J., García-Orduña, F., et al. (2018). The aqueous crude extracts of Montanoa frutescens and Montanoa grandiflora reduce immobility faster than fluoxetine through $\mathrm{GABA}_{\mathrm{A}}$ receptors in rats forced to swim. J. Evid. Based Integr. Med. 23:2515690X18762953. doi: $10.1177 / 2515690 \times 18762953$

Rodríguez-Landa, J. F., Olmos-Vázquez, O. J., da Costa, B. P. D., LimaMaximino, M., Maximino, C., and Guillén-Ruiz, G. (2020). Actions of progesterone on depression-like behavior in a model of surgical menopause are mediated by $\mathrm{GABA}_{\mathrm{A}}$ receptors. Salud. Mental. 43, 43-53. doi: 10.17711/sm.0185-3325.2020.007

Shah, P. C., Trivedi, N. A., Bhatt, J. D., and Hemavathi, K. G. (2006). Effect of Withania somnifera on forced swimming test induced immobility in mice and its interaction with various drugs. Indian J. Physiol. Pharmacol. 50:409.

Shishkina, G. T., Kalinina, T. S., and Dygalo, N. N. (2012). Effects of swim stress and fluoxetine on $5-\mathrm{HT}_{1 \mathrm{~A}}$ receptor gene expression and monoamine metabolism in the rat brain regions. Cell. Mol. Neurobiol. 32, 787-794. doi: $10.1007 / \mathrm{s} 10571-012-9828-0$ 
Sunal, R., Gümüşel, B., and Kayaalp, S. O. (1994). Effect of changes in swimming area on results of "behavioral despair test". Pharm. Biochem. Behav. 49, 891-896. doi: 10.1016/0091-3057(94)90239-9

Takamori, K., Yoshida, S., and Okuyama, S. (2001). Availability of learned helplessness test as a model of depression compared to a forced swimming test in rats. Pharmacology 63, 147-153. doi: 10.1159/000056126

Trunnell, E. R., and Carvalho, C. (2021). The forced swim test has poor accuracy for identifying novel antidepressants. Drug Discov. Today. 26, 2898-2904. doi: 10.1016/j.drudis.2021.08.003

Ulloa, R. E., Díaz-Valderrama, A., Herrera-Pérez, J., León-Olea, M., and MartínezMota, L. (2014). Age differences in the impact of forced swimming test on serotonin transporter levels in lateral septum and dorsal raphe. Behav. Brain Funct. 10, 1-8. doi: 10.1186/1744-9081-10-3

Unal, G., and Canbeyli, R. (2019). Psychomotor retardation in depression: A critical measure of the forced swim test. Behav. Brain Res. 372:112047. doi: 10.1016/j.bbr.2019.112047

Vega-Rivera, N. M., Fernández-Guasti, A., Ramírez-Rodríguez, G., and Estrada-Camarena, E. (2015). Effect of sub-optimal doses of fluoxetine plus estradiol on antidepressant-like behavior and hippocampal neurogenesis in ovariectomized rats. Psychoneuroendocrinology 57, 113-124. doi: 10.1016/j.psyneuen.2015.03.022

Vega-Rivera, N. M., Gallardo Tenorio, A., Fernández-Guasti, A., and Estrada Camarena, E. (2016). The post-ovariectomy interval affects the antidepressantlike action of citalopram combined with ethynyl-estradiol in the forced swim test in middle aged rats. Pharmaceuticals 9:21. doi: 10.3390/ph9020021

Vilela-Costa, H. H., Maraschin, J. C., Casarotto, P. C., Sant'Ana, A. B., de Bortoli, V. C., Vicente, M. A., et al. (2021). Role of 5-HT $\mathrm{T}_{1 \mathrm{~A}}$ and 5$\mathrm{HT}_{2 \mathrm{C}}$ receptors of the dorsal periaqueductal gray in the anxiety-and panicmodulating effects of antidepressants in rats. Behav. Brain Res. 404:113159. doi: 10.1016/j.bbr.2021.113159

Yan, S., You, Z. L., Zhao, Q. Y., Peng, C., He, G., Gou, X. J., et al. (2015). Antidepressant-like effects of Sanyuansan in the mouse forced swim test, tail suspension test, and chronic mild stress model. Kaohsiung J. Med. Sci. 31, 605-612. doi: 10.1016/j.kjms.2015.10.009

Yankelevitch-Yahav, R., Franko, M., Huly, A., and Doron, R. (2015). The forced swim test as a model of depressive-like behavior. J. Vis. Exp. 97:52587. doi: $10.3791 / 52587$

Yates, G., Panksepp, J., Ikemoto, S., Nelson, E., and Conner, R. (1991). Social isolation effects on the "behavioral despair" forced swimming test: effect of age and duration of testing. Physiol. Behav. 49, 347-353. doi: 10.1016/0031-9384(91)9 0055-s

Yuen, E., Swanson, S., and Witkin, J. M. (2017). Prediction of human efficacious antidepressant doses using the mouse forced swim test. Pharmacol. Biochem. Behav. 161, 22-29. doi: 10.1016/j.pbb.2017.09.002

Conflict of Interest: The authors declare that the research was conducted in the absence of any commercial or financial relationships that could be construed as a potential conflict of interest.

Publisher's Note: All claims expressed in this article are solely those of the authors and do not necessarily represent those of their affiliated organizations, or those of the publisher, the editors and the reviewers. Any product that may be evaluated in this article, or claim that may be made by its manufacturer, is not guaranteed or endorsed by the publisher.

Copyright (C) 2022 Rosas-Sánchez, German-Ponciano and Rodríguez-Landa. This is an open-access article distributed under the terms of the Creative Commons Attribution License (CC BY). The use, distribution or reproduction in other forums is permitted, provided the original author(s) and the copyright owner(s) are credited and that the original publication in this journal is cited, in accordance with accepted academic practice. No use, distribution or reproduction is permitted which does not comply with these terms. 